Vol. 11 (4): 903-910 (2021)

\title{
TOBACCO CONSUMPTION AND ITS EFFECT ON EATING BEHAVIOR AMONG BIOLOGY STUDENTS
}

\author{
Djamila MEZOUAR ${ }^{1,2, *}$, Asmaa HAMMOU ${ }^{1}$, Bahia TAYBI ${ }^{1}$, Amine DJILALI ${ }^{1}$ \\ ${ }^{1 *}$ University of Tiaret, Faculty of Natural and Life Sciences, Department of Natural and Life Sciences, BP P 78 \\ Zaâroura 14000, Tiaret, Algeria; \\ ${ }^{2 *}$ Abu Bekr Belkaid University of Tlemcen, Laboratory of Physiology, Pathophysiology and Biochemistry of \\ Nutrition, Department of Biology, Faculty of Natural and Life Sciences, \\ Earth and Universe Sciences, 13000, Algeria;
}

*Corresponding Author Mezouar Djamila, e-mail: djamila.mezouar@univ-tiaret.dz;

Received July 2021; Accepted August 2021; Published September 2021;

DOI: $\underline{\text { https://doi.org/10.31407/ijees11.430 }}$

\begin{abstract}
Objectives. This study aimed to estimate the prevalence of tobacco consumption, the eating behavior and the socioeconomic status among biology students at the Faculty of Natural and Life sciences, University of Tiaret, Algeria during 2019-2020 academic year. Methods. A cross-sectional, anonymous questionnaire-based study of 152 students selected randomly was conducted. Results. The Overall smoking prevalence among participated students was $40.46 \%$. About $55 \%$ of male tobacco users smoke 14 cigarettes daily. Most girls smoke occasionally. The majority of males started smoking at the age of 16. The largest portion of students depended on one or both parents for their income. In terms of diet, students consumed largely foods rich in sugar. In addition, most smokers want to quit because it is dangerous for health. From our survey, it was noted that $73.58 \%$ of consumer and $53.82 \%$ of nonconsumer take the breakfast every day. Conclusion. We must intensify efforts to prevent students from starting smoking by raising awareness of its health risks.
\end{abstract}

Key words: Tobacco consumption, eating behavior, socio-economic status, Biology students. 